ISSN 2338-1523

E-ISSN 2541-576X

Volume 6 No. 1

Mei 2018

\title{
RANCANGAN SISTEM INFORMASI PENJUALAN TAS BERBASIS WEB PADA "GIKITA" ONLINE SHOP
}

\author{
Joko Setiawan ${ }^{1)}$ \\ 1email : awwansetyawan@gmail.com \\ Program Studi Manajemen, Universitas Putera Batam
}

\begin{abstract}
Gikita Online Shop is an online store that sells bag products located in Batam. During this Core Online Shop has been promoting its business using social media like Facebook, Line, Blackberry messenger, Whatsapp and Instagram. The purpose of this research is to design a web-based bag sales information system to facilitate the purchase of goods without having to check social media. Applications designed in the manufacture of bag sale websites using CMS Opencart. The results of the manufacture of this bag sale website is expected to help facilitate in managing the goods to no longer use the manual way of inputting data items and can minimize the occurrence of data errors by using the web.
\end{abstract}

Keywords: Design, System information, Sales, Website, PHP, MySQL, CMS Opencart. 
ISSN 2338-1523

E-ISSN 2541-576X

Volume 6 No. 1

Mei 2018

\section{PENDAHULUAN}

Berbelanja melalui internet atau online shopping juga sering disebut dengan e- commerce. Menurut Husda (2012 : 167),1. e-commerce adalah kegiatan bisnis yang menyangkut konsumen (costumer), manufaktur (manufactures), service2. providers dan pedagang perantara (intermediaries) dengan menggunakan jaringan computer (computer networks) yaitu internet.

Belanja online semakin populer dan menjamur dengan mulai banyak 2 . bermunculan toko-toko online seperti Bibli, Lazada, Tokopedia, Bhineka, OlX, Kaskus, Berniaga, PinkEmma dan lain-lain.

Awalnya berbelanja di internet tidak terlalu diminati alasan yang melatarbelakangi ketidaktertarikan seseorang untuk berbelanja melalui internet seperti antara konsumen dan penjual tidak dapat bertemu langsung, barang yang dibeli tidak dapat dicoba, takut tertipu karena keamanan belanja online belum sepenuhnya memadai, tidak memuaskan dalam hal pelayanan dan produk, pengiriman yang lama dan sistem pemesanan yang membingungkan. Tetapi dengan berbelanja secara online memberikan banyak keuntungan bagi penggunanya yaitu dapat diakses kapan dan dimana saja, lebih mudah untuk melakukan perbandingan harga, produk yang disediakan beraneka ragam.

GIKITA Online Shop merupakan sebuah1. toko online yang menjual produk tas yang berlokasi di batam. Selama ini GIKITA Online Shop sudah mempromosikan usahanya menggunakan media sosial seperti2. Facebook, Line, Blackberry messanger, Whatsapp dan Instagram. Tetapi selama ini penjualan hanya menggunakan sistem3. manual seperti pembukuan manual. Seiring berjalannya waktu penjualan semakin pesat sehingga dirasa perlu untuk memikirkan4. atau memperbaiki sistem secara

berkesinambungan.

\section{Rumusan Masalah}

Bagaimana Membuat sistem informasi penjualan pada GIKITA Online Shop berbasis web?

Bagaimana implementasi sistem informasi penjualan pada GIKITA Online Shop berbasis web?

\section{Tujuan Penelitian}

1. Membuat sistem informasi penjualan pada GIKITA Online Shop berbasis web.

Memimplementasi sistem informasi penjualan pada GIKITA Online Shop berbasis web.

\section{LANDASAN TEORI}

\section{Konsep Dasar Perancangan}

Menurut Kusrini dkk (2007 : 79)

dalam bukunya Tuntunan Praktis Membangun Sistem Informasi Akuntansi dengan Visual Basic dan Microsoft SQL Server perancangan adalah "Proses pengembangan spesifikasi sistem baru berdasarkan hasil rekomendasi analisis sistem". Dalam tahap perancangan, tim kerja harus merancang dalam berbagai kertas kerja mengenai spesifikasi yang dimaksud sesuai kebutuhan pengguna end user melalui alat perancangan yang terstandarisasi.

\section{Aktifitas Dasar Sistem Informasi}

Menurut Laudon (2010, p46-47) adalah sebagai berikut :

Input, Melibatkan pengumpulan data mentah dari dalam organisasi atau dari lingkungan eksternal untuk pengolahan dalam suatu sistem informasi.

Process, Melibatkan proses mengkonversi input mentah ke bentuk yang lebih bermakna.

Output, Mentransfer proses informasi kepada orang yang akan menggunakannya atau kepada aktivitas yang akan digunakan. Feedback, Output yang di kembalikan ke 
ISSN 2338-1523

E-ISSN 2541-576X

Volume 6 No. 1

Mei 2018

anggota organisasi yang sesuai untuk kemudian membantu mengevaluasi atau mengkoreksi tahap Input.

\section{Konsep Dasar Penjualan Online}

Menurut Husda (2012 : 167), E commerce adalah kegiatan bisnis yang menyangkut konsumen (consumer), manufaktur (manufactures), service providers dan pedagang perantara (intermediaries) dengan menggunakan jaringan computer (computer networks) yaitu internet.

Menurut Wong (2010 : 33) electronic commerce adalah pembelian, penjualan dan pemasaran barang serta jasa melalui sistem elektronik. E- commerce meliputi transfer dana secara elektronik, pertukaran dan pengumpulan data. Semua diatur dalam sistem manajemen inventori otomatis.

Dari beberapa pendapat para ahli di atas mengenai pengertian e-commerce dapat disimpulkan bahwa e-commerce adalah kegiatan transaksi jual beli barang dan jasa yang menggunakan sistem elektronik yang terkoneksi dengan internet.

Keuntungan dan kekurangan e-commerce Menurut Husda (2012 : 173), keuntungan yang dapat diambil dari penerapan e-commerce dapat dilihat dari 3 pihak yang terlibat didalamnya yaitu: organisasi, konsumen, dan masyarakat.

1. Bagi organisasi/perusahaan

a. Pasar Internasional

Dengan penerapan e-commerce sebuah perusahaan dapat memiliki sebuah pasar2. internasional. Bisnis dapat dijalankan tanpa harus terbentur pada batas negara dengan adanya teknologi digital. Pihak perusahaan dapat bertemu dengan partner dan kliennya dari seluruh penjuru dunia. Hal ini menciptakan sebuah lembaga multinasional virtual.

b. Penghematan Biaya Operasional

Biaya operasional dapat dihemat. Biaya untuk membuat, memproses, mendistribusikan, menyimpan, dan memperbaiki kembali informasi juga dapat ditekan.

c. Kustomisasi Masal

E-commerce telah merevolusi cara konsumen dalam membeli barang dan jasa. Produk dan jasa dapat dimodifikasi sesuai dengan keinginan konsumen.

d. Berkurangnya kendala inovasi

Yang dimaksud dengan e-commerce, suatu perusahaan dapat menghemat sumber daya karena mereka tidak dipusingkan dengan sulitnya membuat penemuan baru untuk modifikasi produk mereka.

Biaya telekomunikasi yang lebih rendah

Internet lebih murah dari sebuah jaringan yang tambahan halnya digunakan untuk telepon. Adalah lebih murah untuk mengirimkan sebuah fax atau email via internet daripada dial telepon secara langsung.

f. Digitalisasi proses dan produk

Contohnya adalah pada kasus produk software dan audio video, produk digital tersebut dapat dunduh atau dikirim lewat $e$ mail secara langsung ke konsumen melalui internet dalam format digital. Hal ini tentu menghemat waktu dan biaya pengiriman produk.

g. Batasan waktu dapat diatasi

Bisnis dapat dijalankan tanpa mengenal batas waktu karena dijalankan secara on-line melalui internet yang selalu beroperasi tiap hari.

Bagi konsumen

a. Akses penuh 24 jam/7 hari

Konsumen dapat berbelanja atau mengolah berbagai transaksi lain dalam 24 jam sepanjang hari, sepanjang tahun di sebagian besar lokasi.

b. Lebih banyak pilihan

Konsumen tidak hanya memiliki sekumpulan produk yang bisa dipilih namun juga daftar supplier internasional sehingga 
ISSN 2338-1523

E-ISSN 2541-576X

Volume 6 No. 1

Mei 2018

konsumen memiliki pilihan produk yang lebih banyak.

c. Perbandingan harga

Konsumen dapat berbelanja di seluruh dunia dan membandingkan harganya dengan mengunjumgi berbagai situs yang berbeda 2 . atau dengan mengunjungi sebuah website a tunggal yang menampilkan berbagai harga dari sejumlah provider.

d. Proses penghantaran produk yang inovatif Dengan e-commerce proses penghantaranb produk menjadi lebih mudah.

3. Bagi Masyarakat

a. Praktek kerja yang lebih fleksibel

E-commerce memungkinkan masyarakat bisa lebih fleksibel dalam menentukan tempat bekerja, misalnya mereka dapat bekerja dari rumahnya masing-masing tanpa harus pergi ke kantor.

b. Terhubungnya masyarakat dengan masyarakat lain

Masyarakat di Negara berkembang dapat mengakses dan menikmati produk, layanan dan informasi yang mungkin sulit mereka temukan di daerahnya.

c. Kemudahan akses fasilitas public

Masyarakat dengan mudah dapat memanfaatkan layanan public, misalnya layanan kesehatan dan konsultasi serta pembelian resep dokter dengan mengunjungi internet.

Menurut Husda (2012 : 177) walaupun

adanya e-commerce memberi banyakf. keuntungan, masih terdapat berbagai kekurangan dari e-commerce antara lain:

1. Bagi organisasi/perusahaan

a. Keamanan sistem rentan diserang

Masalah keamanan ini menjadi sangat penting karena bila pihak lain yang tidak berwenang bisa menembus sistem maka dapat menghancurkan bisnis yang telah berjalan.

b. Persaingan tidak sehat

Di bawah tekanan untuk berinovasi dan membangun bisnis untuk memanfaatkan kesempatan kesempatan yang ada dapat memicu terjadinya tindakan illegal yaitu penjiplakan ide dan perang harga.

c. Masalah kompabilitas teknologi lama dengan yang lebih baru

Bagi konsumen

a. Perlunya keahlian komputer

Tanpa menguasai keahlian komputer, mustahil konsumen dapat berpartisipasi dalam e-commerce.

Biaya tambahan untuk mengakses internet

Untuk ikut serta dalam e-commerce dibutuhkan koneksi internet yang tentu saja menambah pos pengeluaran bagi konsumen.

c. Biaya peralatan komputer

Komputer diperlukan untuk mengakses internet, tentu saja dibutuhkan biaya untuk mendapatkannya.

d. Resiko bocornya privasi dan data pribadi

Segala hal mungkin terjadi saat konsumen mengakses internet untuk menjalankan $e$ commerce, termasuk resiko bocornya data pribadi karena ulah orang lain yang ingin membobol sistem.

e. Berkurangnya waktu untuk berinteraksi secara langsung dengan orang lain Transaksi e-commerce yang berlangsung secara online telah mengurangi waktu konsumen untuk melakukan proses social dengan orang lain. Hal ini tidak baik karena dikhawatirkan akan dapat mengurangi rasa kepedukian terhadap lingkungan sekitarnya.

Berkurangnya rasa kepercayaan karena konsumen berinteraksi hanya dengan komputer.

3. Bagi masyarakat

a. Berkurangnya interaksi antar manusia

Karena masyarakat lebih sering berinteraksi secara elektronik, dimungkinkan terjadi berkurangnya kemampuan sosial dan personal manusia untuk bersosialisasi dengan orang lain secara langsung.

b. Kesenjangan sosial

Terdapat bahaya potensial karena dapat terjadi kesenjangan sosial antara orang- 
ISSN 2338-1523

E-ISSN 2541-576X

Volume 6 No. 1

Mei 2018

orang yang memiliki kemampuan teknis dalam e-commerce dengan yang tidak, yang memiliki keahlian digaji lebih tinggi daripada tidak.

c. Adanya sumber daya yang terbuang Munculnya teknologi baru akan membuat teknologi lama tidak dimanfaatkan lagi.

d. Sulitnya mengatur internet

Sejumlah kriminalitas telah terjadi di internet dan banyak yang tidak terdeteksi. Karena jumlah jaringan yang terus berkembang semakin luas dan jumlah pengguna yang semakin banyak, seringkali membuat pihak berwenang kesulitan dalam membuat peraturan untuk internet.

\section{Desain Sistem}

Menurut Satzinger, Jackson, dan Burd (2012 : 5), perancangan sistem adalah sekumpulan aktivitas yang menggambarkan secara rinci bagaimana sistem akan

berjalan. Hal itu bertujuan untuk menghasilkan produk perangkat lunak yang sesuai dengan kebutuhan user.

Menurut Kenneth dan Jane (2006 : 12) menjelaskan bahwa perancangan sistem adalah kegiatan merancang detil dan rincian dari sistem yang akan dibuat sehingga sistem tersebut sesuai dengan requirement yang sudah ditetapkan dalam tahap analisa sistem. Selanjutnya lanjut O'Brien dan Marakas (2009 : 639) menjelaskan bahwa perancangan sistem adalah sebuah kegiatan merancang dan menentukan cara mengolah sistem informasi dari hasil analisa sistem sehingga dapat memenuhi kebutuhan dari pengguna termasuk diantaranya perancangan user interface, data dan aktivitas proses.

Menurut Bentley dan Whitten (2009 : 160) melalui buku yang berjudul "system analysis and design for the global enterprise" juga menjelaskan bahwa perancangan sistem adalah teknik pemecahan masalah dengan melengkapi komponen-komponen kecil menjadi kesatuan komponen sistem kembali ke sistem yang lengkap. Teknik ini diharapkan dapat menghasilkan sistem yang lebih baik.

\section{Data Flow Diagram (DFD)}

Data Flow Diagram adalah suatu model logika data atau proses yang dibuat lebih mendetail dibanding diagram konteks yang diperbolehkan, bisa dicapai dengan mengembangkan diagram. Sisa diagram asli dikembangkan ke dalam gambaran yang lebih terperinci yang melibatkan tiga sampai sembilan proses dan menunjukkan penyimpanan data dan aliran data baru pada level yang lebih rendah (Kendall and Kendall 2003:78).

\section{CMS}

CMS (Content Management System) adalah aplikasi web yang berisikan template untuk mengelola isi halaman web. penggunaan content management system tidak memerlukan pengetahuan pemrograman web yang handal karena proses instalasi dan cara penggunaannya sudah user friendly.

\section{Openchart}

Openchart adalah salah satu aplikasi web yang berbasis CMS (Content Management System) khusus untuk penjualan secara online (ecommerce). Openchart merupakan aplikasi webstore (toko online) yang berbasis PHP dan MySQL yang dapat dikelola dengan sistem CMS (Content Management System), dimana untuk penggunaannya bersifat terbuka (OpenSource) dan gratis untuk siapa saja. Aplikasi webstore ini berbasis PHP dan MySQL yang bersifat terbuka (OpenSource) dan gratis untuk digunakan dengan lisensi GNU (General Public License). Openchart dikembangkan oleh Daniel Kerr dan mulai diluncurkan pada bulan Oktober 2008, sampai dengan saat ini aplikasi penjualan online ini sudah mencapai versi 1.5.

Dengan menggunakan aplikasi web online ini, anda dapat dengan mudah 
ISSN 2338-1523

E-ISSN 2541-576X

Volume 6 No. 1

Mei 2018

mengelola toko online untuk penjualan produk-produk milik anda tanpa perlu mempelajari program web lebih jauh. Openchart memiliki fitur-fitur web yang sangat luar biasa untuk webstore atau toko online.

\section{METODOLOGI PENELITIAN}

\section{Kerangka Kerja}

1. Mendeskripsikan Masalah

Mendeskripsikan masalah adalah melakukan perumusan terhadap masalah- masalah yang telah diidentifikasi dari suatu sistem. Merumuskan adalah mengkonsep, menformulakan, mempolakan dan memperjelas suatu hal yang telah diidentifikasi sebelumnya. Merumuskan masalah sangat diperlukan dalam suatu penelitian agar penelitian tersebut menghasilkan kesimpulan yang terkonsep, terformula, terpoladan jelas. Dalam penelitian ini rumusan masalah yang 5 . dilakukan adalah bagaimana cara merancang sistem informasi penjualan tas online berbasis web pada Gikita Online Shop.

2. Menganalisa Masalah

Menganalisa masalah merupakan langkah analisis masalah untuk dapat memahami masalah yang telah ditentukan ruanglingkup atau batasannya. Dengan menganalisa masalah yang telah ditentukan terseut, maka diharapkan masalah dapat dipahami dengan baik. Masalah yang terjadi di Gikita Online Shop adalah sistem penjualan yang masih bersifat manual sehingga sering terjadi human error.

3. Mempelajari Literatur

Mempelajari Literatur atau studi literature adalah tindakan yang dilakukan untuk mempelajari secara ilmiah dan teoritis terhadap masalah-masalah yang telah $_{7}$. dibatasi sebelumnya yang bersumber dari buku, jurnal, karya tulisi lmiah, artikel, tesis dan berbagai sangat diperlukan agar penelitian yang dilakukan berpijak pada landasan teori yang jelas dan benar yang telah dikemukakan oleh para ahli sebelumnya. Dengan melakukan studi literature maka peneitian yang dilakukan tidak mengarang dan mengada-ada sehingga dapat diterima di dunia ilmu pengetahuan dan masyarakat umum.

4. Mengumpulkan Data

Mengumpulkan data dilakukan untuk mengumpulkan semua data-data yang diperlukan dalam penelitian. Teknik yang dilakukan dalam mengumpukan data dalam penelitian ini adalah dengan teknik observasi. Teknik observasi adalah teknik pengamatan langsung kelapangan dengan mencatat data-data yang diperlukan. Selain teknik observasi, peneliti juga melakukan pengumpulan data dan informasi dengan mengadakan tanya jawab secara langsung, diskusi dan konsultasi kepada pihak-pihak yang berkaitan dengan penelitian.

Menganalisa sistem yang sedang berjalan Analisis sistem merupakan gambaran tentang sistem yang saat ini sedang berjalan di Gikita Online Shop, sistem yang digunakan masih sederhana dan manual yaitu dengan menggunakan buku sebagai alat bantu untuk mengetahui pemesanan. Analisis sistem ini bertujuan untuk membuat sistem yang dapat membantu GikitaOnline Shop sehingga dapat lebih efektif dan efisien.

Merancang Aplikasi

Pada tahap ini, peneliti merancang aplikasi yang dapat memberikan manfaat terhadap Gikita Online Shop. Rancangan tersebut dapat dilakukan dengan cara menggambarkan Diagram Konteks (Context Diagram), DFD (Data Flow Diagram), dan ERD (Entity Relationship Diagram), Normalisasi.

Implementasi Aplikasi

Pada tahap implementasi ini dilakukan pembuatan program/aplikasi. Perancangan sistem informasi penjualan tas online di Gikita Online Shop menggunakan CMS 
ISSN 2338-1523

E-ISSN 2541-576X

Volume 6 No. 1

Mei 2018

\section{Opencart.}

Sistem informasi yang berjalan saattini

pada Gikita Online Shop menjelaskan prosedur sebagai berikut :

1. Konsumen memilih barang yang diinginkan melalui media sosial, seperti facebook, blackberry messanger, instagram, line, dan whatsapp dan mendapatkan beberapa informasi tentang barang yang akan dibeli.

2. Admin akan memeriksa ketersediaan stok barang melalui konfirmasi dari Accounting. Jika produk yang diinginkan tidak tersedia, konsumen dapat melakukan pemilihan kembali barang pada stok yang tersedia. 6 .

3. Jika stok barang tersedia, maka konsumen dapat melakukan pemesanan barang dan dilanjutkan ke proses selanjutnya sampai dengan tahap pembayaran barang pesanan.

Setelah itu admin akan menyiapkan barang pesanan dan barang tersebut segera diserahkan kepada konsumen.

Admin membuat nota penjualan untuk konsumen. Selanjutnya konsumen melakukan pembayaran dan mengkonfirmasikan pembayarannya kepada admin Gikita Online Shop. Admin akan memeriksa rekening apakah pembayaran telah sesuai. Setelah itu admin menyiapkan barang pesanan dan barang tersebut segera diserahkan kepada konsumen.

Nota penjualan dilanjutkan oleh accounting dan menghasilkan laporan penjualan barang untuk dapat diserahkan kepada owner. 
ISSN 2338-1523

E-ISSN 2541-576X

Volume 6 No. 1

Mei 2018

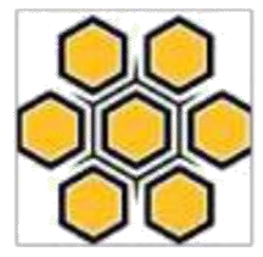

\section{Analisis Sistem yang Diusulkan}

Tabel Sistem Informasi yang Diusulkan

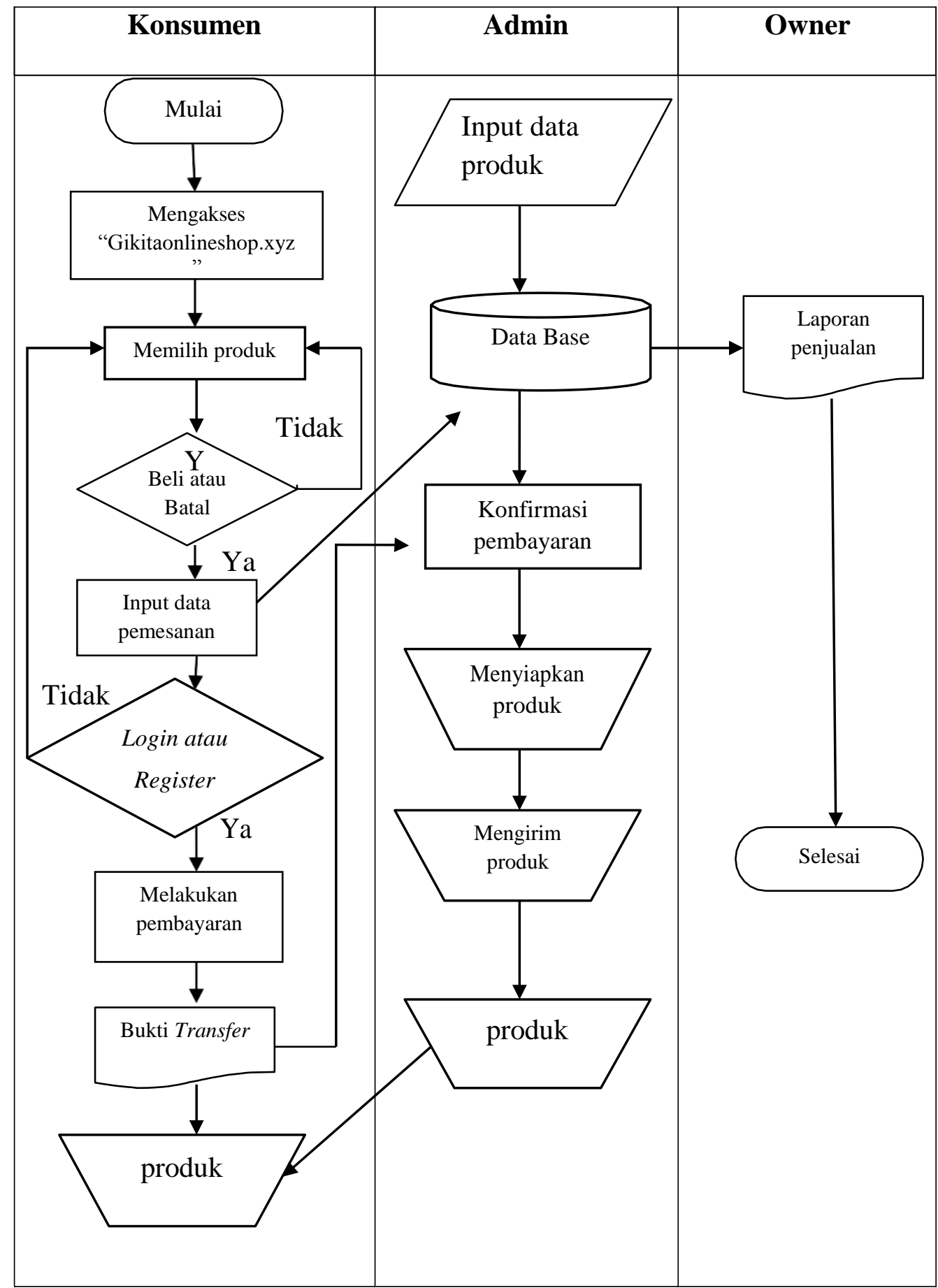


Pada Tabel di atas penulis menjelaskan sistem informasi baru yang diusulkan pada Gikita Online Shop, yaitu sebagai berikut :

1. Kosumen memilih kategori barang dan pembeli melakukan login sebelum melakukan pembelian. Konsumen yang belum memiliki akun diharuskan untuk melakukan registrasi (pendaftaran) terlebih dahulu.

2. Kosumen memilih barang yang sudah ada dan akan masuk ke keranjang belanja pembeli.

3. Kosumen mengisi data pengiriman dan mendapatkan rincian pesanan.

4. Sistem secara otomatis mengirimkan invoice ke halaman kosumen. Kosumen melakukan pembayaran di halaman yang telah disediakan.

5. Admin akan mengecek data pembayaran yang telah dikirim oleh konsumen.

Jika pembayaran lunas, maka admin akan merubah status pesanan menjadi "Complete (Selesai)" dan akan segera mengirim produk yang telah dipesan oleh.

6. Pemilik usaha mendapatkan KESIMPULAN laporan penjualan yang sudah otomatis terekam pada sistem ketika terjadi penjualan.

7. Pada dasarnya, sistem yang diusulkan pada Gikita Online Shop dengan sistem yang telah berjalan sebelumnya tidak jauh berbeda, hanya perbedaannya terletak dalam tata cara proses penginputan data dan penyimpanannya yaitu dari proses manual ke metode terkomputerisasi.

\section{Implementasi}

1. Pendapat Cleaves yang dikutip (dalam Wahab 2008 ; 187), yang secara tegas JURSIMA

Jurnal Sistem Informasi dan Manajemen menyebutkan bahwa: Implementasi itu mencakup "Proses bergerak menuju tujuan kebijakan dengan cara langkah administratif dan politik". Keberhasilan atau kegagalan implementasi sebagai demikian dapat dievaluasi dari sudut kemampuannya secara nyata dalam meneruskan atau mengoperasionalkan programprogram yang telah dirancang sebelumya.

2. Menurut Mazmanian dan Sebastiar (dalam Wahab, 2008 : 68) Implementasi adalah pelaksanaan keputusan kebijakan dasar, biasanya dalam bentuk undang- undang, namun dapat pula berbentuk perintahperintah atau keputusan-keputusan eksekutif yang penting atau keputusan badan peradilan.

3. Menurut Friedrich (dalam Wahab 2008 : 3) Kebijakan adalah suatu tindakan yang mengarah pada tujuan yang diusulkan oleh seseorang, kelompok atau pemerintah dalam lingkungan tertentu sehubungan dengan adanya hambatan- hambatan tertentu seraya mencari peluangpeluang untuk mencapai tujuan atau mewujudkan sasaran yang diinginkan.
Dalam penelitian ini, penulis telah menguraikan pembahasan mengenai "Perancangan Sistem Informasi Penjualan Tas Berbasis Web pada Gikita Online Shop" Ada beberapa kesimpulan yang diambil terhadap penelitian ini antara lain sebagai berikut:

1. Dengan membuat sistem informasi penjualan tas berbasis web pada Gikita Online Shop, kita dapat membantu pengelola agar tidak lagi menggunakan cara manual dalam menginput data barang dan dapat meminimalkan terjadinya kesalahan data dengan https://ejournal.giciku.ac.id/ 
Volume 6 No. 1

Mei 2018

mengunakan web tersebut .

2. Implementasi sistem informasi Penjualan tas berbasis web aplikasi yang dirancang menggunakan CMS Opencart dapat mempermudah pengelola Gikita Online Shop dalam mempromosikan tas ke pembeli secara online.

\section{Saran}

Adapun saran yang diberikan penulis untuk pengembangan dari sistem informasi yang telah dirancang antara lain sebagai berikut:

1. Seiring berkembangnya teknologi seluler, penulis berharap akan ada pengembangan selanjutnya untuk mengakses aplikasi yang telah dikelolah melalui ponsel

2. Untuk mencegah kerusakan atau hilangnya data dalam file, sebaiknya dilakukan

back up secara berkala dan scan terhadap virus yang merusak.

3. Content website perlu ditambah untuk menarik lebih banyak pembeli.

\section{DAFTAR PUSTAKA}

Abdul Wahab dan Solichin. 2008. Pengantar Analisis Kebijakan Publik, Malang: Universitas Muhammadiyah Malang Press.

Abdul Kadir. 2014. Pengenalan Sistem Informasi Edisi Revisi. Andi, Yogyakarta. Agus Mulyanto. 2009. Sistem Informasi Konsep dan Aplikasi.Pustaka Pelajar,

Yogyakarta.

Al-Rosyid Harun, Purnama Bambang Eka, dan Wardati Indah Uly. 2012. IJNS - Indonesian Journal on Networking and Security, ISSN: 2302-5700, "Sistem Informasi Penjualan Buku Berbasis Website pada Toko Buku Standard Book Seller
Pacitan".

Al-Bahra Bin Ladjamudin. 2013. Analisis Dan Desain Sistem Informasi. Penerbit Graha Ilmu, Yogyakarta.

Dianawati, Ajen. (2007). 6 Rahasia Sukses Menjadi Jutawan Internet. Jakarta : Media Kita.

Frieyadie. 2010. Mudah Belajar Pemrograman Database MYQSL dengan Microsoft Visual Basic 6.0. Andi, Yogyakarta.

Indrajani dan Wily. 2007. Seminar Nasional Teknologi 2007, November 2007, ISSN

: 1978 - 9777, "Analisis dan Perancangan Sistem Penjualan Berbasis Web pada PT. Sarang Imitasi".

Kendall, K.E. dan Kendall, J.E.. 2003. Analisis dan Perancangan Sistem Jilid 1.

Jakarta: Prenhallindo.

Kusrini. 2007. Strategi Perancang Dan Pengolahan Basis Data. Yogyakarta : Andi.

Kusrini dkk. (2007). Konsep dan Aplikasi Sistem Pendukung Keputusan. Penerbit Andi, Yogyakarta.

Nandari, Sukadi Bhirawa Anoraga. 2014. Pembuatan Website Portal Berita Desa Jetis Lor. Jurnal Riset Indonesian Journal on Networking and Security.Vol 3 No.3.

O'Brien, James A., Marakas, George M. 2009. Management Information System. 8th Edition. McGraw Hill, New York.

Risti Ongki dan Riasti Berliana Kusuma. 2013. Seminar Riset Unggulan Nasional Informatika dan Komputer FTI UNSA 2013, Vol. 2, No. 1, Maret 2013, ISSN: 2302-1136, "Pembuatan E-Commerce pada Toko Velg https://ejournal.giciku.ac.id/ 
Volume 6 No. 1

Mei 2018

Mobil Limited Edition Berbasis Opencart".

Rudy Tantra. 2012. Manajemen Proyek Sistem Informasi, bagaimana mengolah proyek sistem informasi secara efektif \& efisien. Andi Offset.

Satzinger, W, J., Jackson, B, R., dan Burd, D, S. 2012. Systems Analysis and Design In A Changing World. Boston: Cengage Learning.

Simarmata dan Janner. 2010. Rekayasa Web. Yogyakarta: CV. Andi Offset. 